\title{
Investigation of Oxidation Rate Relationship Between Fatty Acid Contents of St. John's Wort (Hypericum perforatum) Oil and Nettle (Urtica dioica) Seed Oil
}

\author{
Temel Kan Bakır*
}

Department of Chemistry, Faculty of Science and Letters, Kastamonu University, 37200 Kastamonu, Turkey

\section{A R T I C LE I N F O}

\section{Research Article}

Received 10 August 2018

Accepted 18 September 2018

Keywords:

Fatty acid

St. John's wort oil

Nettle seed oil

Fe (III) SCN method

Lipid peroxidation

\section{A B S T R A C T}

Vegetable extract oils are now widely used in health, cosmetics and food fields. The oxidation rates of these industrial oils are closely related to their chemical composition. In this study, fatty acid contents of St. John's Wort (Hypericum perforatum) oil and Nettle seed (Urtica dioica) oil were investigated by gas chromatography (GS-MS) and the effects on lipid peroxidation time were tried to be related. The peroxidation of oil emulsions was carried out at in a ventilated incubation environment $37^{\circ} \mathrm{C}$ and $\mathrm{pH} 7$. Pseudo first order constants of primer oxidation products (hydroperoxides) were calculated by $\mathrm{Fe}$ (III) SCN method and they found for St. John's Wort oil and Nettle seed oil, $(2.05 \pm 0.23) \times 10^{-1}$ and $(6.64 \pm 0.54) \times 10^{-1}$ hour $^{-1}$,respectively. This study was conducted by showed that the oxidation rates of St. John's Wort and Nettle seed oils are closely related to the chemical composition as well as the saturation ratings of fatty acids.

\footnotetext{
*Corresponding Author:

E-mail: temelkan@kastamonu.edu.tr
}

DOI: https://doi.org/10.24925/turjaf.v6i11.1647-1652.2172

\section{Introduction}

Aromatic plants, which have been a source of essential oils since ancient times, are of great interest and are added to different food types to enhance their taste and organoleptic properties (Kelen and Tepe, 2008). In recent years, these substances are generally considered as food and medicine and are used worldwide for preventive and curative treatments. Today many aromatic plants are regarded as an important source for the extraction of compounds with potent antioxidant activity (Bozin et al., 2007). Especially the antioxidant activities of vegetable oils and extracts have been the basis of many applications including raw and processed food preservation, pharmaceuticals, alternative medicine and natural therapies (Kelen and Tepe, 2008). Although nutritional experts appreciate the high levels of unsaturation of fatty acids found in vegetable oils, they cause serious technological problems due to their greater susceptibility to oxidation (Kowalski, 2007).

Urtica dioica is an indigenous plant in Europe and Asia and contains flavonoids, polysaccharides, chlorophyll, carotenoids, tannins, formic acid, salicylic acid, carvacrol and thymol. Many times until this time, it has been reported that the nettle (Urtica dioica) has anticancerogenic, anti-inflammatory, antioxidant, ant analgesic, antiulcer, antiviral, antibacterial and antifungal activities (Binaii et al., 2014; Kanter et al., 2003; Riehemanna et al., 1999). Urtica dioica has been shown to have a strong antioxidant activity and its seeds have been reported to be protective against hepatotoxicity (Yener et al., 2009; Kanter et al., 2005; Skerget et al., 2005). Urtica dioica herbs are used to treat stomach pain, rheumatic pain and colds and coughing in Turkish folk medicine (Gülçin et al., 2004). Monfared et al. (2011) showed that the extract of Urtica dioica may be considered as an antioxidant to be added to edible oils.

Hypericum perforatum, commonly known as Saint John's Wort, is widely used in hot spots worldwide and is traditionally used as a medicinal plant in the Mediterranean region (Smelcerovic et al., 2007; Radusienea et al., 2005). It has been investigated that treatment of mild to moderate depression is effective in anxiety and insomnia problems (Schwob et al., 2004). Commercially available $H$. perforatum products are said to have a wide range of applications. The medical 
properties of $H$. perforatum have been associated with the phenolic composition. $H$. perforatum contains many polyphenolic compounds, including ethanolic extracts, flavonoids and phenolic acids, which show significant antioxidant properties (Silva et al., 2008). This plant is very important in pharmacology, and in many studies, it refers to components such as isolated biologically active hypercysteine, pseudohydrosis, hyperphosphorus, adhyperphorin, procyanidins and xanthones. However, few studies have addressed the composition of $H$. perforatum's essential oil (Pintore et al., 2005; Saddiqe et al., 2010; Çakır et al., 2003). The foliage and seeds of these two plants are sources of important essential fatty acids such as a-linolenic acid and linoleic acid (GuilGuerreroa et al., 2003). This study was carried out for two purposes: (1) to determine the chemical composition of $U$. dioica seed and $H$. perforatum essential oils; and (2) to evaluate the effects of fatty acid compositions of both fats on the peroxidation kinetics (Gül et al., 2012). For this reason, the oils obtained by the cold press method of Hypericum perforatum and Urtica dioica were examined for the time of oxidation at $37^{\circ} \mathrm{C}$ and in the aerated $\mathrm{pH}=$ 7 acetate buffer solution. Copper chloride solution (0.01 $\mathrm{M})$ was used as the oxidation initiator and added in the reaction medium to give $500 \mu \mathrm{M}$.

\section{Materials and Methods}

Absorption measurements were recorded with SHIMADZU UVM-1240 UV-Visible spectrophotometer (Shimadzu Corp., Kyoto, Japan). pH measurements were made using a Metrohm 632 Digital pH meter (Metrohm AG, CH-9100 Herisau, Switzerland). All experiments were performed at $37^{\circ} \mathrm{C}$ in a NUVE BM 30 Circulation Water Bath. All chemical compounds of the analytical reagent grade were purchased from Sigma-Aldrich Co. LLC. Distilled water was used for all operations. The oils used were fresh from "Doğavita Pharmaceutical Food Industry and Trade Inc. (Çiftcizade, Turkey)" and the production methods are summarized in Table 1.

Span 80 and Tween 80 emulsifier mixture for all $\mathrm{O} /$ W emulsions was prepared as HLB value 10. A stock solution of $\mathrm{CuCl}_{2}$, as a chelator for catalytic oxidation of oils, was prepared at a $\mathrm{Cu}$ (II) concentration of $0.01 \mathrm{M}$. Ammonium acetate buffer $(1 \mathrm{M}, \mathrm{pH}=7)$ solution were used for incubation medium.

\section{Preparation of Oil Emulsions}

$0.3 \mathrm{~g}$ of oil was weighed into a $100 \mathrm{~mL}$ volumetric flask. $3 \mathrm{~mL}$ of stock solution was added as an emulsifier (Tween 80 + Span 80, HLB: 10, $0.3 \mathrm{~g}$ in $3 \mathrm{~mL}$ ethanol) (Hassan, 2015). $2 \mathrm{~mL}$ of ethanol and $90 \mathrm{~mL}$ of $\mathrm{NH}_{4} \mathrm{Ac}$ $(1 \mathrm{M}, \mathrm{pH}=7)$ buffer solution was slowly added to the mixture and emulsified by stirring through a magnetic stirrer. Then the emulsion was homogenized in the homogenizer (VELP-OV5).

Measurements by GC-MS for fatty acid methyl ester (FAME) analysis

The oils were analysed by GC-MS fatty acid methyl ester analysis (FAME) according to the IUPAC standard method (International Union of Pure and Applied Chemistry, 1992). Chromatographic measurements were performed using a Shimadzu GCMS QP 2010 ULTRA instrument at RTX-5MS Capillary column (30m; $0.25 \mathrm{~mm} ; 0.25 \mu \mathrm{m})$ and $200^{\circ} \mathrm{C}$ ion source temperature. Accordingly, the esterification pre-treatment was carried out by treating $0.1 \mathrm{~g}$ of sample with $10 \mathrm{ml}$ of $\mathrm{n}$-hexane and adding $0.5 \mathrm{ml}$ of $2 \mathrm{~N}$ methanolic $\mathrm{KOH}$ solution. The oven temperature program is 5 minutes at $90^{\circ} \mathrm{C}, 4^{\circ} \mathrm{C} / \mathrm{min}$ increase from $90^{\circ} \mathrm{C}$ to $250^{\circ} \mathrm{C}, 5$ minutes at $250^{\circ} \mathrm{C}$.

\section{Measurements by GC-MS for Aroma analysis}

Chromatographic measurements were performed at the same ion source temperature and using the same instrument as in the FAME method. But no esterification was done. The oven temperature program is $3 \mathrm{~min}$ at $40^{\circ} \mathrm{C}, 4^{\circ} \mathrm{C} / \mathrm{min}$ increase from $40^{\circ} \mathrm{C}$ to $240^{\circ} \mathrm{C}, 10$ minutes at $240^{\circ} \mathrm{C}, 4^{\circ} \mathrm{C} / \mathrm{min}$ increase from $240^{\circ} \mathrm{C}$ to $260^{\circ} \mathrm{C}$, total $78 \mathrm{~min}$.

\section{Measurements of Lipid Hydroperoxides}

The oxidation of the oils was determined spectrophotometrically at $500 \mathrm{~nm}$ using the ferric thiocyanate method based on the oxidation of the hydroperoxides $\mathrm{Fe}^{2+}$ to $\mathrm{Fe}^{3+}$ (Lea, 1952; Mihaljevic et al.,1996).

For the measurements, $0.1 \mathrm{~mL}$ samples were taken at different time intervals throughout the incubation. The degree of oxidation was measured by sequentially adding ethanol $(4.7 \mathrm{~mL}, 75 \%)$, ammonium thiocyanate $(0.1 \mathrm{~mL}$, $30 \%)$, sample solution $(0.1 \mathrm{~mL})$ and ferrous chloride $(0.1 \mathrm{~mL}$ of $0.02 \mathrm{M}$ in $3.5 \% \mathrm{HCl})$. The mixture was then allowed to stand for 3 minutes and the absorbance at 500 $\mathrm{nm}$ read against the blank containing all components except the oil emulsion. It was observed that the absorbance changes with time gave sigmoidal curves (Watanabe et al.,2005; Yen and Hsieh, 1998).

\section{Statistical Analysis}

Microcal Origin 8.0 (Origin Lab Corp., Northampton, MA) was used for descriptive statistical analysis and graphical drawing. The results were evaluated using SPSS software (SPSS Inc., Chicago, IL, USA) for Windows version 13 (Miller and Miller, 1993).

Table 1 Production methods of used oils

\begin{tabular}{l|ll}
\multicolumn{1}{c|}{ Oil } & \multicolumn{1}{c}{ Oil Botanical } \\
Species & \multicolumn{1}{c}{ Name } & $\begin{array}{c}\text { Obtaining } \\
\text { Method }\end{array}$ \\
\hline $\begin{array}{l}\text { St. John's Wort oil } \\
\text { Nettle seed oil }\end{array}$ & $\begin{array}{l}\text { Hypericum perforatum } \\
\text { Crtica dioica }\end{array}$ & Cold Press \\
Cold Press
\end{tabular}

\section{Results and Discussion}

\section{Investigation of Kinetic Data}

It is very important to study lipid oxidation kinetically and evaluate the degree of lipid oxidation which is the main cause of degradation in food products (Das and Pereira, 1990; Gray, 1978). In this study, the oxidation of cold press oils of Hypericum perforatum and Urtica dioica were studied at $37^{\circ} \mathrm{C}$ in aerated acetate buffered solution $\left(\mathrm{NH}_{4} \mathrm{Ac}\right)$, (Ionic strength, $\left.\mathrm{I}=0.9\right),(\mathrm{pH}=7)$. Copper chloride solution $(0.01 \mathrm{M})$ was used as the oxidation initiator and added in the reaction medium to give $500 \mu \mathrm{M}$. 


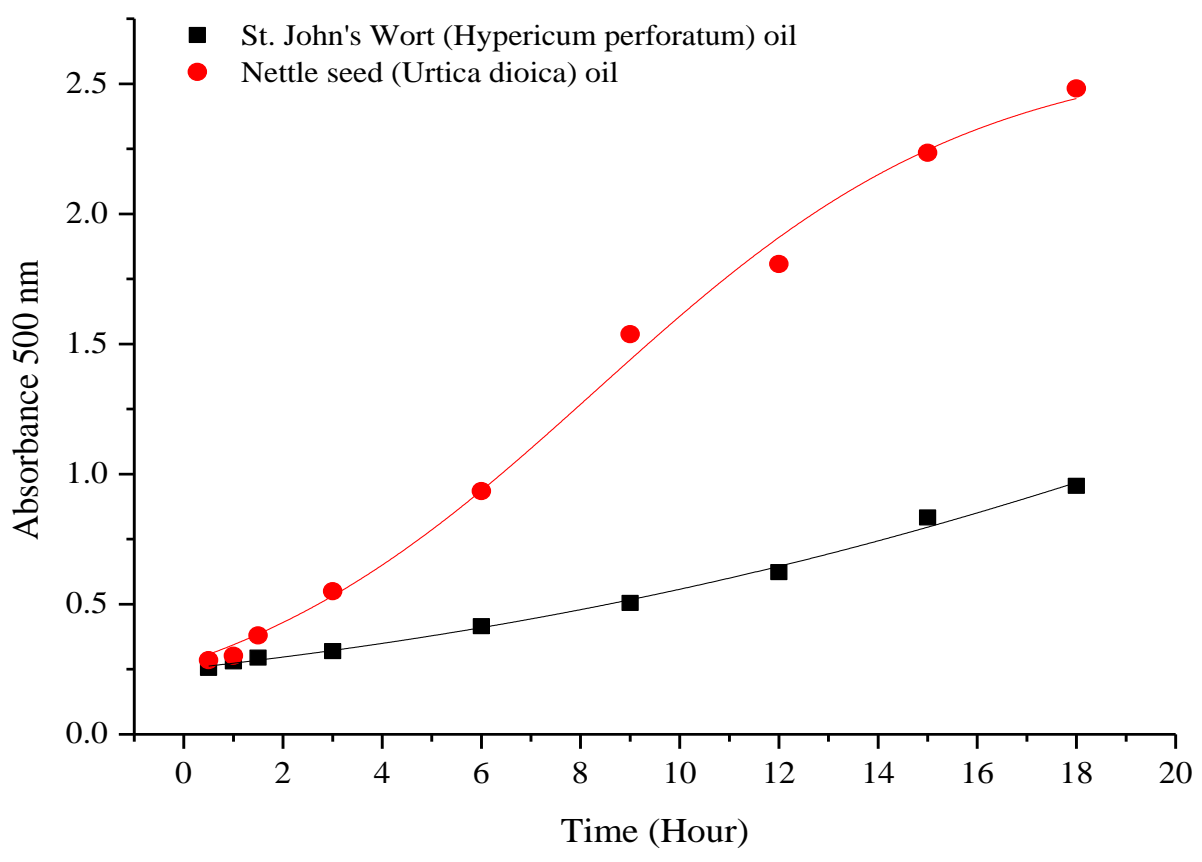

Figure 1 The absorbance-time plot of the oxidation of St. John's Wort oil and Nettle seed oil by Fe (III) SCN method at $37^{\circ} \mathrm{C}$ and $\mathrm{pH}=7.00$

In the experimental part of this work, the primary oxidation products were investigated using the iron (III)thiocyanate spectrophotometric analytical method. During the oxidation of oils, hydroperoxides are formed as primary products with $\mathrm{k}_{1}$ rate constant in accordance with the pseudo first order equation.

$$
L^{k_{1}} \rightarrow \mathrm{LOOH}
$$

Here $\mathrm{L}$ represents lipid and $\mathrm{LOOH}$ represents lipid hydroperoxides. The pseudo first-order rate constant $\left(\mathrm{k}_{1}\right)$ is calculated with the use of Eq. (2) from the slope of the curve $\ln [(1-\mathrm{A}) / \mathrm{A}]$ versus $(\mathrm{t})$.

$$
\ln \left(1-\mathrm{A}_{\mathrm{t}}\right) / \mathrm{A}_{\mathrm{t}}=\ln \left(1-\mathrm{A}_{0}\right) / \mathrm{A}_{0}-\mathrm{kt}
$$

Here $A_{0}$ is the absorbance at the beginning and $A_{t}$ is the absorbance $\left(\mathrm{A}_{500 \mathrm{~nm}}\right)$ at time $\mathrm{t}$, proportional to the total concentration of hydroperoxides. If the maximum absorbance of the oxidation products approaches 1 (i.e. $\left.\mathrm{A}_{\max }=1\right)$, the maximal rate of oxidation can be determined as the first order rate constant (k), (Yıldoğan-Beker et al., 2011).

The oxidations of Hypericum perforatum (St. John's Wort) and Urtica dioica (nettle seed) oils were observed 18 hours with the measurements made by Fe (III) SCN method and results were given in Figure 1. As seen in Figure1, 6 hours was enough to reach the absorbance value 1 , for nettle seed oil, while it was necessary to wait for 18 hours for St. John's Wort oil. This result showed that the rate constant of $\mathrm{k}_{1}$ obtained for St. John's Wort oil is smaller than that of nettle seed oil as seen in Table 2.

GC-MS Data in Fats

GC-MS analyses using the IUPAC standard method after laboratory methylation of St. John's Wort (Hypericum perforatum) oil and Nettle seed (Urtica dioica) oil samples were given in Table 3. The gas chromatograms of the oils were evaluated, and the fatty acids found were denominated by nomenclature based on the number of carbons. According to this, 16 carbon palmitic acid and 18 carbon stearic acid were found in both oils. Oleic acid was found in nettle oil and Petroselinic acid was found in St. John's Wort oil. Linoleic acid was observed as the main fatty acid in both oils and was found much more 1.5 times in the nettle seed oil (Table 3). In Table 3, the percentages of saturated fatty acids (SFA), monounsaturated fatty acids (MUFA), polyunsaturated fatty acids (PUFA) and trans fatty acids (TFA) were given for both oils. Total saturated fatty acids ( $\Sigma$ SFA) were found to be close to each other according to fat type.

When the oils of St.John's Wort (Hypericum perforatum) and Nettle seed (Urtica dioica) were examined in terms of total monounsaturated fatty acids $(\Sigma$ MUFA), the results followed the line St. John's Wort oil $>$ Nettle seed oil. When the percentages of total polyunsaturated fatty acids ( $\Sigma$ PUFA) were examined, the results followed the line Nettle seed oil > St. John's Wort oil. When the percentage of total trans fatty acids is found ( $\Sigma$ TFA), it is found that only St. John's Wort oil is contained.

According to this, total unsaturated fat ratios were $85.42 \%$ for St. John's Wort oil and $85.68 \%$ for Nettle seed oil. Both fat saturated and unsaturated fat ratios were found to be approximately the same. The degree of saturation and unsaturation of oils is closely related to the oxidation rate and shelf life of oils (Akoh and Min, 2002).

Because of, St. John's Wort oil contains many antioxidant compounds compared to nettle seed oil (Figure 2), the rate constant of $\mathrm{k}_{1}$ for St. John's Wort oil was found smaller than that of nettle seed oil (Figure 1 and Table 2). Also it was found that for both oils, Linoleic acid content was different (Table 3 ). 
Table 2 The rate constants of primary oxidation products formation from oil $-\mathrm{Cu}(\mathrm{II})$ system.

\begin{tabular}{l|cc}
\multicolumn{1}{c|}{ Oil Species } & $\mathrm{k}_{1} \pm \mathrm{S}_{\mathrm{k}}\left(\mathrm{hour}^{-1}\right) \times 10^{-1}$ & $\mathrm{r}^{2}$ \\
\hline St. John's Wort (Hypericum perforatum) oil & $2.05 \pm 0.23$ & 0.907 \\
Nettle seed (Urtica dioica) oil & $6.64 \pm 0.54$ & 0.974 \\
\hline
\end{tabular}

$\mathrm{k}_{1}$ : pseudo-first order rate constant with respect to hydroperoxides formation (measured by Fe (III)-SCN method)

Table 3 Fatty acid composition and trans fatty acid content (\%) of essential oils prepared by fatty acid methyl ester analysis (FAME) method of St. John's Wort oil and Nettle seed oil

\begin{tabular}{|c|c|c|}
\hline \multirow{2}{*}{ Fatty acid } & \multicolumn{2}{|c|}{ Fatty acid content \pm SD $(g$ per $100 \mathrm{~g})$} \\
\hline & St. John's Wort (Hypericum perforatum) oil & Nettle seed (Urtica dioica) oil \\
\hline C $14: 0^{*}$ & 0.07 & 0.05 \\
\hline C 16:0 & 8.86 & 7.61 \\
\hline C 17:0 & 0.04 & 0.05 \\
\hline C 18:0 & 4.76 & 5.03 \\
\hline C18:0 $(9,12,15$ cyclopropil $)$ & 0.04 & 0.09 \\
\hline C 20:0 & 0.47 & 0.53 \\
\hline C23:0 (iso-20) & 0.24 & 0.1 \\
\hline$\Sigma \mathrm{SFA}^{*}$ & 14.48 & 13.46 \\
\hline C16:1w7 & 0.1 & 0.04 \\
\hline C $18: 1$ c9,c12 & 0.1 & - \\
\hline C18:1w9 & - & 23.66 \\
\hline C19:1 c6 & 34.23 & - \\
\hline C20:1w9 & 0.38 & 0.31 \\
\hline $\mathrm{C} 22: 1 \mathrm{c} 13$ & 0.11 & - \\
\hline$\Sigma$ MUFA* & 34.92 & 24.01 \\
\hline C16:2n-6,9 & - & 0.06 \\
\hline C18:2w6 & 44.35 & 61.61 \\
\hline $\mathrm{C} 21: 2 \mathrm{c} 11, \mathrm{c} 14$ & 1.07 & - \\
\hline$\Sigma$ PUFA* & 45.42 & 61.67 \\
\hline C $19: 3$ c9, t111,t13 & 5.08 & - \\
\hline$\Sigma$ Trans FA & 5.08 & - \\
\hline
\end{tabular}

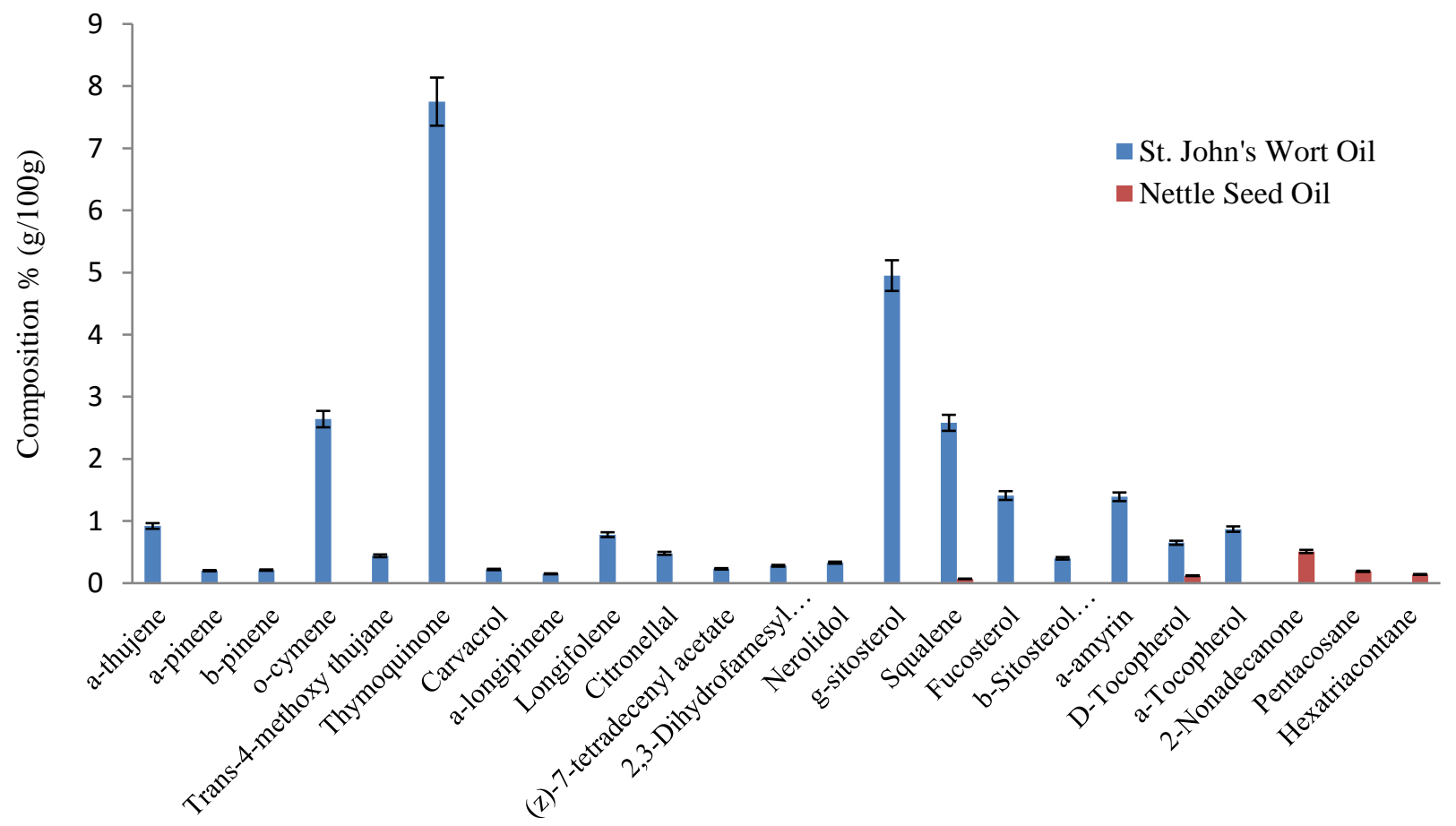

Figure 2 Aroma composition obtained without pre-treatment in essential oil of Hypericum perforatum and Urtica dioica. The calculated results are given as mean $\% 95$ confidence interval. 
When the Table 3 alone is evaluated, it can be interpreted that for both oils, it is approximately the same for the oxidation rates. However, Table 2 and Figure 1 clearly show that the oxidation rates observed for the formation of primary products in these two oil emulsion environments are quite different. So, because we can explain this, the fatty acid content of the oils is not sufficient by itself. Therefore, the flavour composition of the oils was obtained by the GC-MS method without esterification pre-treatment in both oils (Figure 2). Accordingly, it was observed that St. John's Wort oil contains many antioxidant compounds compared to nettle seed oil. Alpha amyrin, thymoquinone, alpha and beta pinene, alpha thujene, o-cymene, gamma sitosterol, and fucosterol in the content of St. John's Wort oil have been studied extensively by researchers (Singh et al., 2014; Yoshida and Niki, 2003; Okoye et al., 2014). A number of researchers have found that they have antioxidant properties at the end of their studies with herbal extracts containing these compounds (Fabiyi et al., 2012; Inci et al., 2013; Thompson et al., 1963). Staniek and Gille (2010) said that thyokinone found in cells is important for antioxidant properties. Melo et al. (2011) studied the improvement of pancreatic damage by their a-b-aminin anti-inflammatory, antinociceptive, and antioxidant properties. Tiwari and Troy (2015) have said that they protect the immune system by inhibiting the free radicals of fucosterol and increase protective antioxidant enzymes such as superoxide dismutase, catalase and glutathione peroxidase. In the study of Kelen and Tepe (2008), they showed the antioxidant properties of Salvia species containing alpha and beta pinene, alpha thujene.

In our study, squalene was detected in both St. John's Wort oil and nettle seed oil. However, it was found in very low values in the nettle seed oil. Squalene is a triterpene, a compound that can carry oxygen directly to the cell, independently of the haemoglobin, and has antitumour activity (Güneş, 2013). Dessi et al. (2002) also showed that squalene mainly acts as a peroxyl radical scavenger. Conforti et al. (2005) reported the antioxidant effect of squalene in a lipid peroxidation model. In summary, Amarowicz (2009) has reported that squalene is a hydrophilic natural antioxidant.

\section{Conclusion}

In this light, the following conclusions were reached regarding the oxidation rates of St. John's Wort oil and nettle seed oil. Although the ratio of unsaturated fat in both oils is the same, it has been found that the compounds showing natural antioxidant properties in St. John's Wort oil are much more than the nettle seed oil. These natural antioxidant compounds are undoubtedly part of the human diet in the treatment of certain diseases and also act as inhibitors of lipid oxidation in their environment.

\section{References}

Akoh CC, Min DB. 2002. Food Lipids, Chemistry, Nutrition, and Biotechnology. Second Ed., Revised and Expanded Ed., Marcel Dekker, Inc., New York.
Amarowicz R. 2009. Squalene: A natural antioxidant? Eur. J. Lipid Sci. Technol. 111:411-412.

Binaii M, Ghiasi M, Farabi SMV, Pourgholam R, Fazli H, Safari R, Alavi SE, Taghavi MJ, Bankehsaz Z. 2014. Biochemical and hemato-immunological parameters in juvenile beluga (Huso huso) following the diet supplemented with nettle (Urtica dioica). Fish \& Shellfish Immunology. 36:46-51.

Bozin B, Mimica-Dukic N, Samojlik I, Jovin E. 2007. Antimicrobial and Antioxidant Properties of Rosemary and Sage (Rosmarinus officinalis L. and Salvia officinalis L., Lamiaceae) Essential Oils. J. Agric. Food Chem. 55:78797885.

Cakir A, Mavi A, Yıldırım A, Duru ME, Harmandar M, Kazaz C. 2003. Isolation and characterization of antioxidant phenolic compounds from the aerial parts of Hypericum hyssopifolium L. by activity-guided fractionation. Journal of Ethnopharmacology. 87:73-83.

Das NP, Pereira TA. 1990. Effects of Flavonoids on Thermal Autoxidation of Palm Oil: Structure-Activin Relationships. JAOCS. 67, 4.

Conforti F, Statti G, Loizzo MR, Sacchetti G, Poli F, Menichini F. 2005. In vitro antioxidant effect and inhibition of aamylase of two varieties of Amaranthus caudatus seeds. Biol Pharm Bull. 28:1098-1102.

Dessi MA, Deiana M, Day BW, Rosa A, Banni S, Corongiu FP. 2002. Oxidative stability of

polyunsaturated fatty acids: effect of squalene. Eur J Lipid Sci Technol. 104:506-512.

Gray JI. 1978. Measurement of Lipid Oxidation:A Review. Journal of The American Oil Chemists' Society. 55:539546.

Guil-Guerreroa JL, Rebolloso-Fuentesa MM, Torija Isasa ME. 2003. Fatty acids and carotenoids from Stinging Nettle (Urtica dioica L.). Journal of Food Composition and Analysis. 16:111-119.

Gül S, Demirci B, Baser KHC, Akpulat HA, Aksu P. 2012. Chemical Composition and In Vitro Cytotoxic, Genotoxic Effects of Essential Oil from Urtica dioica L. Bull Environ Contam Toxicol. 88:666-671. DOI 10.1007/s00128-0120535-9

Gülçin İ, Küfrevioğlu Öİ, Oktay M, Büyükokuroğlu ME. 2004. Antioxidant, antimicrobial, antiulcer and analgesic activities of nettle (Urtica dioica L.). Journal of Ethnopharmacology. 90:205-215.

Güneş FE. 2013. Medical Use of Squalene as a Natural $\begin{array}{lll}\text { Antioxidant, MÜSBED. 3(4):220-228. DOI: } & \end{array}$ 10.5455/musbed.20131213100404

Fabiyi OA, Atolani O, Adeyemi OS, Olatunji GA. 2012. Antioxidant and Cytotoxicity of a-Amyrin acetate fraction from Bridelia ferruginea Leaves. Asian Pacific Journal of Tropical Biomedicine. 981-984.

Hassan AK. 2015. Effective Surfactants Blend Concentration Determination for $\mathrm{O} / \mathrm{W}$ Emulsion Stabilization by Two Nonionic Surfactants by Simple Linear Regression. Indian J Pharm Sci. 77(4):461-469.

Inci M, Davarci M, Inci M, Motor S, Yalcinkaya FR, Nacar E, Aydin M, Sefil NK, Zararsiz I. 2013. Anti-inflammatory and antioxidant activity of thymoquinone in a rat model of acute bacterial prostatitis. Human and Experimental Toxicology. 32(4):354-361.

International Union of Pure and Applied Chemistry. 1992. Standard Methods for the Analysis of Oils, Fats and Derivatives. 1st Suppl. to 7th Edn. Pergamon Press, Oxford (UK).

Kanter M, Coskun Ö, Budancamanak M. 2005. Hepatoprotective effects of Nigella sativa L and Urtica dioica $L$ on lipid peroxidation, antioxidant enzyme systems and liver enzymes in carbon tetrachloride-treated rats. World Journal of Gastroenterology. 11(42): 6684-6688. 
Kanter M, Meral I, Dede S, Cemek M, Ozbek H, Uygan I, Gunduz H. 2003. Effects of Nigella sativa L. and Urtica dioica L. on Lipid Peroxidation, Antioxidant Enzyme Systems and Some Liver Enzymes in CCl4-Treated Rats. J. Vet. Med. 50:264-268.

Kelen M, Tepe B. 2008. Chemical composition, antioxidant and antimicrobial properties of the essential oils of three Salvia species from Turkish flora. Bioresource Technology. 99: 4096-4104.

Kowalski R. 2007. GC Analysis of Changes in The Fatty Acid Composition of Sunflower And Olive Oils Heated with Quercetin, Caffeic Acid, Protocatechuic Acid, and Butylated Hydroxyanisole. Acta Chroma Tographica.18.

Lea CH. 1952. Methods for Determining Peroxide in Lipids. J Sci

Food Agric. 12(3):586-594.

Melo CM, Morais TC, Tome AR, Brito GAC, Chaves MH, Rao VS, Santos FA. 2011. Anti-inflammatory effect of a,bamyrin, a triterpene from Protium heptaphyllum, on cerulein-induced acute pancreatitis in mice. Inflamm. Res. 60:673-681.

Mihaljevic B, Katusin-Razem B, Razem D. 1996. The Reevaluation

of the

Ferric Thiocyanate Assay for Lipid Hydroperoxides with Special Considerations of the Mechanistic Aspects of the Response. Free Radical Bio Med. 21(1):5363.

Miller JC, Miller JN. 1993. Statistics for Analytical Chemistry, 3rd. Ed. Ellis Horwood, Prentice

Monfared M, Kamkar A, Khaligh SG, Javan AJ, Asadi F, Basti AA. 2011. Antioxidative effects of Iranian Urtica dioica $L$. Extracts on the oxidation of sunflower oil. Journal of Medicinal Plants Research. 5(18):4438-4445.

Okoye NN, Ajaghaku DL, Okeke HN, Ilodigwe EE, Nworu CS, Okoye FBC. 2014. beta-Amyrin and alpha-amyrin acetate isolated from the stem bark of Alstonia boonei display profound anti-inflammatory activity. Pharm Biol. 52(11):1478-1486.

Pintore G, Chessa M, Boatto GP, Cerri R, Usai M, Tirillini B. 2005. Essential Oil Composition of Hypericum perforatum L. var. angustifolium DC Growing Wild in Sardinia (Italy). Journal of Essential Oil Research. 17:533-535.

Radusienea J, Judzentiene A, Bernotiene G. 2005. Essential oil composition and variability of Hypericum perforatum L. growing in Lithuania. Biochemical Systematics and Ecology. 33: 113-124.

Riehemanna K, Behnkec B, Schulze-Osthoja K. 1999. Plant extracts from stinging nettle (Urtica dioica), an antirheumatic remedy, inhibit the proinammatory transcription factor NF-UB FEBS. Letters. 442:89-94.
Saddiqe Z, Naeem I, Maimoona A. 2010. A review of the antibacterial activity of Hypericum perforatum L. Journal of Ethnopharmacology. 131:511-521.

Schwob I, Bessiere JM, Masotti V, Viano J. 2004. Changes in essential oil composition in Saint John's wort (Hypericum perforatum L.) aerial parts during its phenological cycle. Biochemical Systematics and Ecology. 32:735-745.

Silva BA, Malva JO, Dias ACP. 2008. St. John's Wort (Hypericum perforatum) extracts and isolated phenolic compounds are effective antioxidants in several in vitro models of oxidative stress. Food Chemistry. 110:611-619.

Singh S, Das SS, Singh G, Schuff C, Lampasona MP, Catalán CAN. 2014. Composition, In Vitro Antioxidant and Antimicrobial Activities of Essential Oil and Oleoresins Obtained from Black Cumin Seeds (Nigella sativa L.). BioMed Research International. Hindawi Publishing Corporation,10. http://dx.doi.org/10.1155/2014/918209

Skerget M, Kotnik P, Hadolin M, Hras AR, Simoni M, Knez Z. 2005. Phenols, proanthocyanidins, flavones and flavonols in some plant materials and their antioxidant activities. Food Chemistry. 89:191-198.

Smelcerovic A, Spiteller M, Ligon AP, Smelcerovic Z, Raabe N. 2007. Essential oil composition of Hypericum L. species from Southeastern Serbia and their chemotaxonomy. Biochemical Systematics and Ecology. 35:99-113.

Staniek K, Gille L. 2010. Is thymoquinone an antioxidant? BMC Pharmacology. 10 (Suppl 1):A9.

Thompson MJ, Robbins WE, Baker GL. 1963. The nonhomogeneity of soybean sterol-"gamma-sitosterol". Steroids. 2(5):505-512.

Tiwari BK, Troy DJ. 2015. Seaweed Sustainability: Food and Non-Food Applications. Lipids.209,Academic Press,London.

Watanabe Y, Ishido E, Fang X, Adachi S, Matsuno R. 2005. Oxidation Kinetics of Linoleic Acid in the Presence of Saturated Acyl L-Ascorbate. JAOCS. 82:389-392.

Yen GC, Hsieh CL. 1998. Antioxidant Activity of Extracts from Duzhong (Eucommia ulmoides) Toward Various Lipid Peroxidation Models in Vitro. J Agr Food Chem. 46:39523957.

Yener Z, Celik İ, İlhan F, Bal R. 2009. Effects of Urtica dioica $L$. seed on lipid peroxidation, antioxidants and liver pathology in aflatoxin-induced tissue injury in rats. Food and Chemical Toxicology. 47:418-424.

Yıldoğan-Beker B, Bakır T, Sönmezoğlu İ, İmer F, Apak R. 2011. Antioxidant Protective Effect of Flavonoids on Linoleic Acid Peroxidation Induced by Copper(II)/Ascorbic Acid System. Chemistry and Physics of Lipids. 164: 732739.

Yoshida Y, Niki E. 2003. Antioxidant effects of phytosterol and its components. J Nutr Sci Vitaminol (Tokyo). 49(4):277-80. 